\title{
Vejen fra tvang til frihed \\ i Grundtvigs liv og forfatterskab
}

\section{Af William Michelsen}

»..Ordet Tvang ... finder jeg ... er det eneste rette.« Grundtvig om statskirken på den grundlovgivende rigsforsamling 1849.

(Se Grundtvig-Studier 1987 s. 15)

Hvordan kan det være gået til, at den mand, der i sit 42. år vilde tvinge en teologisk professor til at nedlægge sit embede p. gr. af falsk lære, fra sit 49. år blev den mest urokkelige tilhænger af frihed i åndslivet i Danmark? - Man kan ikke undgå at stille dette spørgsmål, hvis man vil betragte Grundtvigs liv og forfatterskab som en helhed, og det må man nødvendigvis gøre, når man ser, at Grundtvigs person og forfatterskab ikke er til at komme uden om, uanset om man i ét og alt er enig med ham eller ej.

\section{Forhistorien}

Nu må man huske, at Grundtvig ikke altid har været ortodoks lutheraner, selv om han til sin død vedblev at være en stor beundrer af Luther og modstander af romerkirken. Han var ganske vist opdraget $\mathrm{i}$ et hjem, hvori den lutherske ortodoksi som Paul $V$. Rubow i en forelæsning træffende udtrykte det havde »overlevet « pietisme og rationalisme. Og det var, hvad Grundtvig selv i sit hyldestdigt til faderen 5. december 1810 priste ham for: at han var en »Præst $\mathrm{i}$ Luthers Aand « $\mathrm{i}$ en tid, »hvor man Lutheri Liig omfører!« Men fra april 1801 til december 1810 havde Grundtvigs forhold til den lutherske ortodoksi været mer end kritisk. Grundtvig daterer i sin dagbog 1804 dette frafald til sin læsning af T.C. Bruuns digt »Skriftemaalet «, hvis indhold i forgrovet form svarer til Voltaires kritik af kristendommen i digtet »Le Pour et le Contre«, men med en mere utvetydig stillingtagen, »og ... Kaput var Ortodoxien«, som det udtrykkelig hedder i dagbogens selvbiografi.

Indtrykket af Steffens og Oehlenschläger fra 1802-04 trængte ikke igennem hos Grundtvig, før han i 1805 mødte Constance 
Leth og hørte hende synge. Kaput var nu den kyniske rationalist, hvis dragt Grundtvig havde iført sig fire år før. Udgangspunktet for den udvikling, som derved begyndte, har Grundtvig skildret i sit første brev til Chr. Molbech fra maj 1808 og bl.a. vedlagt det digt, som er trykt i Grundtvig-Studier 1989-90, »Synet «. Det er behandlet i en kronik i Information af Jørgen Elbek (20.1.1987), som han siden har optrykt i en essaysamling.

Digtet viser, at Grundtvig ikke blot bygger sin opfattelse af poesien på visioner, men at han selv virkelig har oplevet sådanne: han troede, at det var hans virkelige søster, der viste sig for ham, men opdagede, at det var et syn, da han vilde trykke hende $\mathrm{i}$ hånden (»Jeg fatted Luften«). Men digtet viser tillige, at det var denne vision, der igangsatte Grundtvigs religiфse udvikling. Han beskriver i digtet et andet syn: det, der viste sig for ham ved indtrykket af Constance Leth:

Jeg saa en Kvinde - Solens Fader

Omsvøbte hende med sin Glands,

I Hende Blomsters Myriader

Sig havde flettet til en Krands.

Af Andagt luede mit Hjerte,

Af andagtsfulde Kærlighed:

Ej mer paa Jorden jeg begærte,

End evig taus at knæle ned,

Ej maa jeg knæle - Spejlet brødes,

Og Billedet kan ej genfødes.

Da søsteren i digtet havde trøstet ham med ordene:

Besku det evige, det Høje!

Og Du skal nyde Sjelefred,

havde han svaret:

Ja, var jeg Aand som Du og kunde

Det gaadefulde Liv udgrunde,

Beskue ham som er og var,

Men vi i Spejlet kun beskue,

Og naar det brydes, maa Vi grue. 
Det var dette, der var sket for Grundtvig, da han forstod, at tilbedelsen af Constance Leth var ham nægtet. Dette spejlbillede af det evige var brudt itu. Men da søsteren opfordrede ham til at se et andet spejlbillede af det evige i grænsefloden mellem aser og jætter i den nordiske mytologi, fulgte han rådet, og resultatet ses $\mathrm{i}$ hans første fremstilling af den i tidsskriftartikelen »Om Asalæren «, der er dateret 22. maj 1807. Den efterfulgtes af bogen »Nordens Mytologi« 1808 og hans »Optrin af Kæmpelivets Undergang i Nord « 1809. Grundtvigs forhold til kristendommen blev i denne periode mere positivt end i 1801-1805. Han daterer selv sin tilbagevenden til 1806. Men forholdet mellem kristendom og asalære var stadig ganske uklart:

Høje Odin! Hvide Krist!

Sletted ud er Eders Tvist,

Begge Sønner af Alfader.

Sådan synger koret i »Maskeradeballet i Dannemark«, 1808.

Det var denne uklarhed, Grundtvig formelt ophævede, da han i marts holdt og i april 1810 udgav sin dimisprædiken under titelen »Hvi er Herrens Ord forsvundet af hans Hus?« - Reelt og fuldstondig afklaret blev forholdet mellem den nordiske mytologi og kristendommen i Grundtvigs liv og forfatterskab først, da han havde skrevet sin såkaldte »Anden Udgave « af »Nordens Mythologi« i 1832 med en helt ny tekst, et helt nyt titelblad, sit »Rimbrev til nordiske Paarørende« med ordene:

Frihed lad være vort Løsen i Nord,

Frihed for Loke saavelsom for Thor,

og en »Indledning«, der gælder hele hans følgende forfatterskab.

Sin dimisprædiken havde han tilegnet sin far med et digt, hvori det hedder: »Du har fuldendt og jeg skal nu begynde«, men det holdt meget hårdt for Grundtvig at holde dette tilsagn, da det kom til stykket. Da han i maj 1811 blev ordineret til præst og derefter indsat som personel kapellan for sin far i Udby, så han sig tvungen til at tage afstand fra den nordiske mytologi, den livsopfattelse, der havde ført ham tilbage til en 
religiøs livstydning overhovedet. Dette kunde ikke undgå at sætte sig spor $\mathrm{i}$ hele Grundtvigs senere forfatterskab.

\section{Den »saelsomme forvandling"}

At være forpligtet til at blive præst var Grundtvigs bestemmelse, før han blev født. Han har fortalt historien derom i tilegnelsesdigtet til sin mor foran i digtsamlingen »Kvædlinger« 1815. Grundtvig var den fjerde søn i ægteskabet, og de tre ældre var alle sat til at studere teologi. Skulde den fjerde nu også? var der en af husets gæster, der spurgte. Moderen var ikke sen til at svare:

»Skal min sidste Trøie springe

Blir han dog til Bogen holdt.«

Hun fandt det selv »ilde«, at hendes »Løfte lød saa stolt «, men var dog så bundet af dette løfte, at hun satte drengen til at læse, da han var fire år, hvilket mærkede ham for livet.

Spørgsmålet er nu, hvorledes denne moderens bestemmelse påvirkede sønnens liv og forfatterskab. - Grundtvig var jo ikke den eneste, der af sine forældre var blevet bestemt til at blive præst. Søren Kierkegaard var ligeledes af sin far bestemt til at blive præst, hvilket i allerhøjeste grad prægede hele hans forfatterskab. Og hans angreb på »den officielle Christendom« fik f.eks. betydning for min farfar og oldefar og for utallige andre, for hvem kristendommen netop blev »officiel«, dvs. pligtmæssig. Og det gjaldt ikke blot for de her nævnte (der af deres far var bestemt til at blive præster), men strengt taget for enhver, der ikke ved sin fødsel tilhørte et andet anerkendt trossamfund.

Der var også $\varnothing$ konomiske grunde til, at Grundtvigs forældre vilde have deres søn til at hjælpe den gamle far i embedet, så han kunde beholde det til sin død. Grundtvig vidste rimeligvis, at en sådan ansøgning ikke vilde blive efterkommet, da han i første omgang svarede $j a$ på sin fars anmodning. Men da faderen forlangte, at han skulde gå til kongen $\mathrm{i}$ audiens og sige, at han følte et særligt kald til at blive sin fars kapellan, svarede han $n e j$. For dét følte han ikke. - Da han trods alt i december 1810 brød sammen og vendte hjem til Udby, skyldtes det ikke blot et 
strengt brev fra hans mor, overanstrengelsen ved hans historielæsning og -undervisning og hans disposition til en maniodepressiv psykose, men især uoverensstemmelsen mellem hans ord i udgaven af dimisprædikenen og hans vægring ved at gå i audiens til kongen. Det var på dette punkt, han $\mathrm{i}$ januar 1811 gav efter - og opnåede at blive sin fars kapellan.

Hvor voldsomt et brud dette skridt fremkaldte i Grundtvigs stilling som forfatter i dansk litteratur, ser man formentlig tydeligst $\mathrm{i}$ den form, han gav udgivelsen af de »Optrin af Norners og Asers Kamp«, han havde digtet $f \phi r$ krisen i 1810. Ikke blot ændrede han slutningen på disse optrin sådan, at de hedenske helte (i strid med de oldtidsdigte, der var hans kilde) blev omvendt til kristendommen, men han begrundede dette $i$ en fortale, der slutter med følgende ord:

„Gid imidlertid disse Tidernes og Historiens Vilkaar maatte drive de af vore Skjalde, der ei ere kristelige i Tro, til dog at være det i Sang! Ligesom den religiøse Grundtone, der gaar gennem Hedenolds Kvad, under alle Troens og Tidens Omskiftelser, sikkrer dem Yndest hos alle høiere stemte Sjæle, saaledes vilde i Sandhed Nutidens Digtere sørge bedst for deres Eftermæle ved overalt at knytte deres Kvad til den Gud, der staar fast, selv naar Himlene sammenrulles. Vist nok er det tungt, naar saadanne Grunde skal nøde Digteren til at være, hvad han saa naadefuld kaaredes til at være: Guds Mund og Profet, men i en Tidsalder, da Hovmod og Egennytte hersker, maa Man være glad, naar Vandet $\emptyset$ ses af det rette Kildevæld, om dette end ikke er i Hjertet, og sige med den hellige Povel: det er dog Kristus, som forkyndes, i hvor det gaar, enten det er paa Skrømt eller for Alvor.« (US I s. 557.)

Efter disse ord er der ingen grund til at undres over, at hverken Oehlenschläger eller J.P. Mynster kunde tænke sig at samarbejde med Grundtvig, da han henvendte sig til dem i breve fra juni og december 1812. Når Grundtvig mente sig forpligtet af sin tro og sin ordination til at opfordre samtidens digtere til åbenlyst hykleri, kunde ærlige progressive forfattere ikke samarbejde med ham. 
Det er nok rigtigt, når Kaj Thaning skriver, at »krisen har chokeret ham til ydmyghed « (Menneske først - 1963, s. 18). Krisen var både logisk og psykologisk velbegrundet. Men den har givet ham et chok, som han har været længe om at forvinde. Hovedsagen må være den, at han i perioden 1811-1826 har taget ordinationen og embedet som præst meget tungt - tungere end andre præster i Danmark. Dette må hænge sammen med, at han har følt sig tvunget ind i det.

Det strider ikke mod denne opfattelse, at Christian Thodberg i Grundtvig-Studier 1986 har fremdraget en prædiken fra 1833, hvori Grundtvig fortæller, hvordan han i 1811 fik mod til efter sin ordination at tiltræde kapellanembedet og prædike for bønderne dér. Han har naturligt nok været betænkelig ved denne situation. Det havde været lettere for ham at være præst for helt fremmede mennesker i en anden by, f.eks. Præst $\varnothing$, og han søgte faktisk embedet dér i efteråret 1810 , men fik det jo først i 1821. At det trods alt lykkedes i Udby, skyldtes ikke nogen vision, men Jesu ord til apostelen Peter: "...da mødte Herren mig i Skoven ... usynlig, men virkelig i Aanden «, som det hedder i prædikenen.

3. Grundtvigs holdning til prosteembedet 1810-11, 1825-26 og 1831-32

Jeg er ikke i tvivl om, at det religiøse standpunkt, Grundtvig gennem krisen i 1810 nåede frem til, forblev det faste punkt $\mathrm{i}$ hans livsanskuelse og hans tro til hans død. Det førte ham først og fremmest til det historiesyn, som er udtrykt i de tre Verdenskrøniker fra 1812, 1814 og 1817. Men dette historiesyn krævede en nærmere filosofisk begrundelse og fik den i det menneskesyn, som udtrykkes $\mathrm{i}$ hans betragtninger over menneskelivet $\mathrm{i}$ tidsskriftet Danne-Virke 1816-1819. I 1833 kalder han det »Den Mosaisk-Christelige Anskuelse af Livet $\mathrm{i}$ alle sine Retninger og alle sine Yttringer « (US VI s. 12). Men han adskiller i 1832 denne anskuelse fra den kristne tro. (US V s. 401) Det er imidlertid ikke denne udvikling, jeg her vil skildre.

Hensigten med denne artikel er at finde den vej, ad hvilken Grundtvig nåede frem til erkendelsen af friheden. Udgangspunktet er, at de bratte ændringer i Grundtvigs holdning til 
præsteembedet i 1810-11, i 1825-26 og i 1831-32 har deres årsag $\mathrm{i}$, at han på forhånd var bestemt til at blive præst. I 1810 blev han - dels af sine forældre, dels af sin samvittighed - tvunget til at opgive en lovende forfatterkarrière i København for i stedet at blive sin fars hjælpepræst i Udby. I 1825 følte han sig af sin ordination som præst forpligtet til at forsvare den danske statskirke - dvs. den kristne kirke - mod en teologisk professor p. gr. af dennes lærebog $\mathrm{i}$ »Catholicismens og Protestantismens Kirkeforfatning, Lære og Ritus«. Da han i den anledning blev anklaget og dømt for injurier, nedlagde han sit embede og levede på ny som forfatter. Men da en kreds af hans kirkelige venner i 1831 ansøgte om at måtte danne en fri, luthersk menighed uden for statskirken, erklærede han sig villig til at blive deres præst og vedlagde et skrift »Om den Clausenske Injuriesag «, hvori han hævdede den »Grundsætning «: »altid at unde Næsten samme Frihed, som Man selv giør Krav paa«. - Dette var en helt anden holdning end den, han i 1811 havde udtrykt i slutningen af fortalen til »Optrin til Norners og Asers Kamp«. Den var også forskellig fra den, han havde hævdet i »Kirkens Gienmæle« 1825.

Når Grundtvig i 1825 udtrykte sig så skarpt, at han kunde blive anklaget og dømt for injurier i 1826, må det skyldes, at han i 1810 selv var blevet tvunget ind i det præsteembede, som han nu vilde tvinge professoren til at opgive at undervise studenterne til. Da professoren ikke vilde nedlægge sit embede, nedlagde Grundtvig sit. Han optrådte dermed lige så konsekvent, som da han i 1811 drog konsekvensen af udgivelsen af sin dimisprædiken i 1810 og lod sig ordinere til sin fars kapellan.

Når Grundtvig i 1831 erklærede sig villig til på ny at blive præst, skyldtes det, at der var en menighed, der ønskede ham til præst i en fri luthersk kirke uden for statskirken. Men han fik kun lov til at prædike til aftensang (uden løn) i en kirke inden for statskirken. Og når Grundtvig i 1839 blev ansat som hospitalspræst ved Vartov kirke, stadig inden for statskirken, skyldtes det, at han mente at kunne forene denne præstegerning med sit forfatterskab. - Det er disse holdningsskift, jeg vil søge nærmere begrundet i det følgende.

Ét er at kende årsagen til dem i den forpligtelse, hans forældre havde pålagt ham, og den ordination, han tog så alvorligt. Et andet er at forstå den begrundelse, han fandt for den frihed, han 
fra 1832 hævdede, ikke blot som kristen, men overhovedet som menneske.

Efter min mening er der god sammenhæng ikke blot i Grundtvigs liv før og efter 1832, men også i hans tænkning og livsanskuelse før og efter 1832. Spørgsmålet er: hvori ligger denne sammenhang?

Kaj Thaning hævder i sin disputats »Menneske først « (1963), at det var under udarbejdelsen af Indledningen til »Nordens Mythologi« 1832, gennembruddet skete, ligesom han har påvist, at den såkaldt »mageløse Opdagelse « af den apostolske trosbekendelse som det afgørende kriterium på ægte kristendom skete midt under udarbejdelsen af afhandlingen $\gg \mathrm{Om}$ den sande Christendom « i 1825, hvilket for mig er den eneste mulighed for at forstå meningen $\mathrm{i}$ denne afhandling. For så vidt må jeg give Thaning ret, både i påvisningen af stedet, hvor den mageløse opdagelse, og stedet, hvor frihedssynet bryder igennem i Grundtvigs forfatterskab. Men jeg kan ikke give Thaning ret $i$, at det er en ændring af Grundtvigs livssyn eller livsanskuelse, der sker. Det benægter Grundtvig selv udtrykkeligt i fortalen til »Haandbog i Verdens-Historien« I, 1833 (US VI s. 12 øverst). Og dermed bliver det spørgsmål stående: hvordan kan det være gået til, at Grundtvig er kommet videre fra den situation, han havde låset sig fast $\mathrm{i}$ ved at lægge H.N. Clausens lærebog ved siden af den apostolske trosbekendelse og påvise, at de ikke stemmede overens?

\section{Havde Grundtvig ikke ret?}

Der er næppe tvivl om, at Grundtvigs kritik af H.N. Clausens kirkebegreb i selve bogen "Kirkens Gienmæle « var berettiget. Det hævder bl.a. professor Leif Grane i sin artikel »Om Grundtvigs kirkelige anskuelse « i bogen »De Levendes Land, Grundtvig 1984«, Kbh. 1984. Injuriedommen beskæftiger sig imidlertid overhovedet ikke med dette spørgsmål, som Grundtvig anså for hovedsagen. Men når Grundtvig i fortalen siger, at H.N. Clausen »har stillet sig i Spidsen for alle den christelige Kirkes Fiender og Guds Ords Foragtere i Landet «, så er det en virkelig personlig krænkelse, altså en injurie, selv om Grundtvig længere nede siger, »at Striden fra min Side slet ikke er person- 
lig, og ingenlunde blot videnskabelig «. Den sidste tilføjelse betyder, at det ikke er en teologisk strid, men en strid om retten til at være »Præste-Lærer i Kirke-Skolen«. Den drejer sig om, hvad der må kraves af den, der skal vaere prast, og især af den, der skal være lærer for dem, der skal være præster. Det var dette krav, som var Grundtvigs personlige anliggende - ikke blot $\mathrm{i}$ bogen »Kirkens Gienmæle«, men ved Grundtvigs egen ordination i 1811 og ved hans egen funktion som præst i Udby, i Præst $\varnothing$, i København og på Christianshavn. Det er her, forklaringen ligger på den voldsomhed, hvormed Grundtvig i sit »Fejdebrev« til H.N. Clausen »paastaaer, at, som ærlig Mand, maae han enten giøre den Christelige Kirke høitidelig Afbigt for sin uchristelige og forargelige Lærdom, eller nedlægge sit Embede og aflægge sit christne Navn«. Grundtvig kalder det »min ufravigelige Paastand, i den Christelige Kirkes og Menigheds Navn«. Grundtvig gør ved denne fortale al saglig debat umulig og identificerer sig med den kirke, han mod sit eget oprindelige $\emptyset$ nske var blevet tvunget til at være præst $i$.

I og for sig var det naturligvis Grundtvigs ret at forsvare den luthersk-evangeliske kirke, også mod teologiske professorer. Og naturligvis havde Grundtvig ret til at bøje sig for sine forældres $\emptyset$ nske om, at han skulde blive præst. Det er også naturligt, at han følte sig som præst resten af sit liv. Men den citerede påstand er et krav til professoren, som denne - hvis han skulde være »ærlig Mand « - under ingen omstændigheder kunde opfylde. Hvis han nedlagde sit embede, fordi han fastholdt sine meninger, vilde han have erklæret dem for ukristelige, og hvis han »aflagde sit kristne navn«, vilde han have modsagt sin dåb. Han måtte derfor - ikke blot af økonomiske og politiske grunde, men også i kraft af sin samvittighed »som ærlig mand« blive i sit embede og fortsætte sit arbejde som exeget - hvad han da også gjorde, endog efter Grundtvigs død i 1872. En holdning, Grundtvig anerkendte i sit afsluttende skrift »Om den Clausenske Injuriesag « 1831. Dog under den forudsætning, at det blev tilladt dem, der ikke anerkendte hans lære, at træde ud af statskirken. Hvilket dengang ikke var muligt.

Også H.N. Clausen var altså tvunget til at blive i statskirken, hvis han ikke vilde tilslutte sig den reformerte kirke og forlade sit embede. Men det $\emptyset$ nskede hverken han eller Grundtvig. Hvad Grundtvig ønskede, var i fortalen til »Kirkens Gienmæle«: 
»at det borgerlige Baand paa Kirkens Fiender maa løses, saavidt det kan bestaae med borgerlig Orden, og Kirkens Forsvar overlades til den selv«; og i sit skrift fra 1831 minder Grundtvig om, at han - efter at have nedlagt sit embede - foreslog den løsning, at han og andre gammeldagstroende selv kunde træde ud af statskirken.

Grundtvig bruger $i$ et brev til Ingemann fra 4. november 1825, som Grete Bøje har fremhævet (Grundtvig-Studier 1984) et udtryk, som han skriver at han er sikker på, at Ingemann ikke vil misforstå: »Bogen har jeg paa en Maade selv skrevet, men Fortalen har vor Herre gjort«. (Grundtvig-Ingemann s. 73). Meningen er ikke, at Grundtvig vil fralægge sig ansvaret for fortalen, men som det længere nede i brevet hedder: »kun da, naar vi klarlig indse Sandheden af, hvad der uvilkaarlig paatrænger sig os, kun da kan vi rettelig sige, det er moralsk umuligt at holde det tilbage.« Med andre ord: det er - som det også udtrykkelig hedder - en »Inspiration«, der har overbevist Grundtvig om »Sandheden « af, hvad han har skrevet i denne fortale. - Grundtvig skriver selv i slutningen af samme brev: »I $\emptyset$ vrigt er jeg nær ved at tro, at, havde Fortalen ikke været som den er, vilde Modstanderne ligegyldig overset det hele...« Hvilket er en ganske rimelig begrundelse for den.

Der er ingen tvivl om Grundtvigs overbevisning om, at han havde ret såvel i bogens tekst som $\mathrm{i}$ fortalens ord. Men der er heller ingen tvivl om, at disse påstande for H.N. Clausen var uantagelige. Også hans overbevisning måtte naturligvis respekteres. Dette indså Grundtvig ikke i 1825. - Brevvekslingen mellem ham og Ingemann viser, at det, de begge forudså nødvendigheden af, var en klar adskillelse mellem kristne og ikkekristne. Det var en sådan, Grundtvig ønskede at fremkalde. Netop med sin fortale.

H.N. Clausen var hverken kirkehistoriker eller kirkepolitiker, men professor i fortolkningen af Det nye Testamente og elev af den tyske filosof og teolog Schleiermacher, der havde studeret og oversat Platon og overført sin filosofiske og filologiske metode fra den klassiske filologi til teologien. Det var denne metode, H.N. Clausen havde indført på Københavns Universitet til stor tilfredshed for studenterne. Men ét er en sund skriftfortolkning, et andet en klar bestemmelse af, hvad der er agte kristendom. Skulde menigmands tro nu være afhængig af teologernes nye 
fortolkningsprincipper? Det var dette spørgsmål, der satte Grundtvig i harnisk og fik ham til at opgive Luthers krav om en ligefrem fortolkning af Bibelen. Det var i denne situation, han fandt sit virkelig nye synspunkt, som påvist af Kaj Thaning $\mathrm{i}$ Grundtvig-Studier 1981: Kirken er aldre end Skriften. Det var dette synspunkt, han formulerede ved at kræve, at enhver fortolkning af Skriften skulde stemme overens med den ældste kristne trosbekendelse. I sin begejstring over denne »mageløse opdagelse « overså Grundtvig, at modstanderen dog måtte have ret til at hævde sit synspunkt, som også hidtil havde været Grundtvigs: Skriftprincippet. Årsagen var, at Grundtvig følte situationen som krig imod den ægte kristendom.

Det spørgsmål, jeg nu stiller, er dette: hvornår er det gået op for Grundtvig, at han havde gjort H.N. Clausen uret ved i sin fortale til Kirkens Gienmæle at påstå, at han »i denne Bog har stillet sig i Spidsen for alle den Christelige Kirkes Fiender og Guds Ords Foragtere i Landet « og »at, som ærlig Mand, maa han enten giøre den Christelige Kirke høitidelig Afbigt for sin uchristelige og forargelige Lærdom, eller nedlægge sit Embede og aflægge sit christne Navn « (US IV s. 397)?

Denne påstand, tilføjede Grundtvig, »kan jeg aldrig, uden selv at udelukke mig af Kirken, tage tilbage«. Det var denne tilføjelse, som blev afgørende for Grundtvig, da han den 8. maj 1826 direkte spurgte statskirkens overhoved, kong Frederik VI, i en audiens, om han anså Grundtvig for injuriant. Kongen svarede ja. Og Grundtvig søgte samme dag selv sin afsked fra det embede, hvori han havde følt sig forpligtet til at handle, som han havde handlet.

At dette er den virkelige grund til hans afskedsansøgning, fremgår klart af den minutiøse redegørelse for handlingsforløbet, som cand.theol. Grete Bøje har fremlagt i Grundtvig-Studier 1984 (se specielt s. 49). Den dybereliggende årsag har både Grundtvig selv og forskningen fremsat forskellige meninger om. Man må også tage de personlige forhold i betragtning, ikke blot de psykologiske, men også de økonomiske (som i 1810-11). Ifølge en familietradition sagde Lise Blicher i de afgørende dage direkte til Grundtvig: »Jeg ser godt, hvad der piner dig i disse dage: hensynet til mig og børnene. Men gør trøstig, hvad vor Herre byder dig. Han vil nok vide at sørge for mig og børnene.« Denne holdning har fra første gang, jeg hørte den, givet mig den største 
respekt for Grundtvigs første hustru som hans faste støtte i kampårene (der omfatter hele tiden fra deres forlovelse i 1811 til og med ansættelsen ved Vartov i 1839). Lises holdning er også udgangspunkt for min betragtning i denne artikel: praesteembedet er nøglepunktet til forståelsen af sammenhoengen $i$ Grundtvigs liv og forfatterskab.

Grundtvig blev tvunget ind i præsteembedet i 1811, og han følte sig tvunget til at træde ud af det, da det ikke lykkedes ham at tvinge H.N. Clausen til at træde ud af embedet som lærer for de vordende præster. Selv havde han oprindelig ønsket at blive universitetslærer i historie og som sådan at demonstrere kristendommens sandhed, som det havde været hensigten med hans tre Verdenskrøniker. Embedet i Præst $\varnothing$ var det første præstekald, han havde søgt, og det eneste sognepræstekald, han fik - efter 10 års forløb. Embedet som præst ved Vartov kirke blev han overtalt af kongen til at søge - Grundtvig troede ikke, biskop Mynster vilde fremme hans ansøgning, og vilde ikke søge, medmindre han fik det. »De kan jo give mig Deres ansøgning «, svarede kongen, og dermed var sagen afgjort. For resten af Grundtvigs liv. Han vilde have mulighed for anden virksomhed ved siden af, og hans gennembrud $\mathrm{i}$ forholdet til samtiden var hans forelæsninger over samtidens historie i 1838: „Mands-Minde $\ll$.

\section{Efter dommen}

Hvorledes gik det da til, at Grundtvig i 1831 - netop da han var kommet hjem fra sin tredie forskningsrejse til England med et stort filologisk-historisk pionérarbejde bag sig - erklærede sig villig til at blive præst på Christianshavn?

Grundtvigs hidtidige holdning til præsteembedet var fra 1810 bestemt af tvang: moderens løfte før han blev født, faderens krav til ham i 1810, samvittighedskrisen i årets slutning, fornægtelsen af asalæren i 1811, den »sælsomme forvandling « af hans historiesyn i Verdens Krønike 1812 og alt, hvad dermed fulgte, protesten mod den tyske idealistiske filosofi i Danne-Virke 181619 - altsammen følger af, at Grundtvig rettede sig efter sin samvittighed og blev lydig mod sine forældre, fordi han i første omgang havde svaret ja på sin fars krav. Han så sig tvunget af 
den konsekvens, han - som påvist af Henning Høirup - havde lært i sin filosofiundervisning som student, idet han betragtede modsigelsens grundsatning som en ontologisk lov - ikke blot en regel for logisk tænkning. Da det i 1815 gik op for ham, ved læsningen af Kants »Kritik der reinen Vernunft«, at det var til en sådan formel logisk lov, Kant havde reduceret det, der for Grundtvig var tilværelsens grundlov, faldt det ham efter min mening ikke et øjeblik ind, at han selv skulde have tænkt fejl. Han måtte forkaste Kant, ligesom han var blevet nødt til at forkaste først Schelling, så Fichte og dermed hele den moderne idealistiske filosofi på samme måde, som den kristne kirke i oldtiden forkastede gnostikerne - som det ses af manuskriptet »Grenzen der Menschheit « (trykt i Grundtvig-Studier 1984, jf. min kommentar sst. 1985), der dog kun omtaler Schelling. Forkastelsen af Kant ses først i Verdens-Krøniken 1817. Grundtvigs kulturprogram blev nu enheden af Kirke, Stat og Skole, dvs. religion, politik og videnskab, som det ses i 4 . bind af DanneVirke. Det var dette program, han talte for som præst i 1821-26 og drog konsekvensen af $\mathrm{i} »$ Kirkens Gienmæle« 1825.

Hvordan kunde det da gå til, at Grundtvig - kun fem år efter, at han i 1826 havde nedlagt sit præsteembede i konsekvens af »Kirkens Gienmæle« - på ny erklærede sig villig til at blive præst, et halvt år efter, i 1832, endda inden for den danske statskirke?

Det må bero på den krise, Grundtvig kom ud i efter dommen i 1826. Denne krise viser sig ikke i hans forfatterskab i årene 1826-1830. Resultatet ses først efter de tre forskningsrejser til England, han fik støtte til af Frederik VI. Det beror ikke blot på rejseindtrykkene, men også på de resultater, han kom til, og det værk, han udgav efter hjemkomsten: »Nordens Mythologi« 1832.

Krisen i 1810 beroede på, at Grundtvig blev tvungen til at vælge mellem hedenskab og kristendom. Og det standpunkt, han bekendte sig til i fortalen til »Optrin af Norners og Asers Kamp« 1811, var ingen tilfredsstillende løsning. Grundtvig kunde ikke slippe sin kærlighed til den nordiske mytologi og til middelalderens (halvvejs hedenske) danske poesi og historie. Men så indtraf der i 1815 en litterær begivenhed, som blev af meget stor betydning for Grundtvig, skønt det varede længe, før han selv og vi andre, hans læsere - forstod dens rækkevidde: udgivelsen (i 
København) af det angelsaksiske heltedigt Beowulf. Det var denne begivenhed, Grundtvig - der straks havde kastet sig over digtet, refereret dets indhold i Danne-Virke, renset dets tekst og gendigtet det på dansk i 1820 - vendte tilbage til, da han var kommet sig over dommen. Hvorfor? - Ikke blot af almindelig historisk interesse, men fordi dette digt viste, at digteren var kristen, og at de kvad, som i digtet blev fremført i den danske kong Hrodgars hal, havde et elementært kristent indhold. Kløften mellem hedenskab og kristendom var altså ikke så dyb, som Grundtvig havde forestillet sig før 1815. De kristne tildigtninger i »Norners og Asers Kamp« var altså ikke så urimelige, som Grundtvig havde forestillet sig, da han skrev dem i 1811. Ja, det viste sig endog i England, da han fordybede sig i den glemte angelsaksiske oldtidslitteratur, at kristendom og heltedigtning $i$ nordisk stil gik hånd $i$ hånd på den anden side af Vesterhavet allerede $i$ tiden for kampelivets undergang $i$ nord. (Jævnfør de to artikler herom i Grundtvig-Studier 1989-90 af Bent Noack og den engelske professor S.A.J. Bradley.) Grundtvig behфvede altså ikke laengere at vare bange for at miste sin kristendom ved at vende tilbage til studiet af den nordiske mytologi.

Den lange indledning til Grundtvigs »Anden Udgave«, dvs. helt nye fremstilling af »Nordens Mythologi« kom derfor til at indeholde det første udtryk for hans nye kulturprogram: hans adskillelse af »Anskuelse « og »Tro«, og hans uforfærdede fremhævelse af de nordiske folks og deres kulturs betydning for Europas fremtidige kultur.

Men allerede før denne fremstilling var færdig og indledningen til den skrevet $\mathrm{i}$ sin endelige form, var det, en menighed havde henvendt sig til Grundtvig og bedt ham blive deres præst. De ønskede - ligesom den tyske menighed på Christianshavn - at danne en fri luthersk menighed i den samme kirke som den tyske menighed. Da Grundtvig svarede ja, vedlagde han ansøgningen en erklæring om sin holdning til den kristne tro og, hvad der $\mathrm{i}$ denne forbindelse er det vigtigste, den lille bog »Om den Clausenske Injuriesag«, hvis afsluttende ord bør citeres i deres helhed:

»Og hermed være da den aabne Kampe-Fard Professoren anbefalet, der ikke blot vilde betrygge ham mod de Grundtvigske Angreb, han nu uden Føie klager over, men betrygge 
ham, selv i Modstandernes Øine, den Høiagtelse, jeg er stolt af at besidde hos mange Hæders-Mænd, som ingenlunde dele min Tro, eller billige mine Tanker, men som agte det, med mig, for en Grund-Sætning, alle ærlige, ædle og ægte kraftige Naturer maae have tilfælles: aldrig at snoe sig fra sine Ord, eller skye Opoffrelser for sin Overbeviisning, men altid at unde Næsten samme Frihed, som Man selv giør Krav paa, og altid at lade haant om kiødeligt RygStyd i aandelig Kamp!« (US V s. 364.)

Bogen indeholder- foruden denne tydelige indrømmelse af den ret, Grundtvig i fortalen til »Kirkens Gienmæle« ikke havde forstået at give H.N. Clausen - svaret på, hvorledes Grundtvig nu i 1831 vilde se roligt på, om Clausen blev »summus theologus « i statskirken. Betingelsen var, at alle »gammeldags troende « kristne i så fald fik lov at træde ud af statskirken og danne deres egen kirke. Hensigten fremgår klart af koncepten til Grundtvigs erklæring, der er trykt i »Breve til og fra N.F.S. Grundtvig « II s. 202-204: »at de om Troens og Salighedens Sag grundstridige Partier i Stats-Kirken, paa en eller anden Maade maa kirkelig adskilles «, hvilket lempeligst og på den »mest velgiørende Maade« kunde ske, »naar det allernaadigst tillades de Præster, hvis Samvittighed ikke længer tillader dem at beklæde Embeder i Stats-Kirken at gaae ud deraf med deres mange eller faa Tilhørere, og kirkelig sørge for sig selv.«

Men det fik de altså i 1832 ikke lov til. - Forklaringen på, at det $d o g$ ikke blev til et brud mellem Grundtvig og statskirken, kan ses af den redegørelse, som Grundtvig umiddelbart efter en audiens - denne gang ikke hos kongen, men hos statsminister Stemann - nedskrev, og som er udgivet af Gustav Albeck i »Grundtvigs Dag- og Udtogsbøger« (I s. 455-457): man фnskede ikke engelske tilstande $i$ Danmark. I det øjeblik Grundtvig nævnede, at han havde været i England, blev statsministeren pludselig opmærksom: dette var væsentligt. Man ønskede ikke, at Grundtvig - som John Wesley $i$ London - skulde træde ud af kirken og holde gudstjeneste i et uindviet hus. Hvilket kort efter var lige ved at ske.

Og Grundtvig фnskede det efter min mening heller ikke selv. For han havde forlængst - i sin »Udsigt over Verdens-Krøniken« 1817 s. $352 \mathrm{f}$ - principielt taget afstand fra Wesleys udtræeden af 
den engelske statskirke, fordi den ikke var nødvendig. Wesley var ikke som Luther blevet »udstødt « af kirken. Derfor kunde hans udtræden ikke betragtes som »Guds Værk.« Grundtvig skriver i 1817 om Wesley:

»han viste Mangel paa den Kraft og den Tillid til Gud, som hører til, trods al Haan og hvert Tungebaand, at blive i Kirken, til man udstødes, og bekæmpe dens Vanart, istedenfor at vælge den nemme Udvei, at stifte en Sekt, som aldrig leder til noget Godt, men til Sværmerie og aandelig Hovmod, kort sagt, at han manglede de Egenskaber, en Reformator maa besidde, naar Værket skal lykkes, blive ikke hans men Guds.«

Grundtvig skriver, at John Wesley påstod, at han ikke selv havde »skilt sig fra Kirken, men udelukdes af dens Forstandere, uagtet han førde dens Lærdom, men deri havde han Uret, da man aldrig udelukde ham som Medlem, men kun hindrede ham i Lære-Embedet, og den londonske Biskop Edvard Gibsons Hyrdebrev imod ham var baade yngre end hans Vinkel-Kirke, og manglede Lovskraft.«

Disse ord fra 1817 kan Grundtvig ikke have glemt. De beskriver en situation, der $i$ en sådan grad ligner den, Grundtvig vilde have sat sig $\mathrm{i}$, hvis den gudstjeneste han havde lejet lokale til på et pakhusloft og bekendtgjort, var blevet til virkelighed, at Grundtvig ikke kan have glemt, hvad han havde skrevet i 1817. Grundtvig ønskede ikke at træde ud af kirken, men »at de om Troens og Salighedens Sag grundstridige Partier i Stats-Kirken, paa en eller anden Maade, maa kirkelig adskilles«. Og det var netop det, der skete, da Grundtvig ved kongelig resolution fik tilladelse til at holde aftensangs-gudstjeneste i Fredriks-kirken.

Det var ingen ideel, principiel løsning. Men det var en løsning, Grundtvig kunde være tilfreds med. Nu kunde han prædike uden den tunge forpligtelse, der før havde trykket ham og fået ham til at forpligte andre til at have samme tro som han selv. Det var denne befrielse, der gjorde Grundtvig til en rolig og glad kristen, en virksom forfatter og salmedigter, en elsker af frihed $\mathrm{i}$ åndsliv og kirkeliv og en vogter af friheden i dansk politik. Han vidste nu, at 
Tvang til Tro er Snak i Taaget, Hjertet værger sig med Fynd, Tvang til Skrømt, som Pave-Aaget,

Det er Tvang til Løgn og Synd;

Kun til Helved kan Man tvinges,

Mens til Himlen blot der ringes,

Frihed følger Sandheds Aand!

(Sang-Værk I nr. 41, 1836.)

Man tager næppe fejl i at mene, at det var den hermed præciserede holdningsændring fra skriftet »Om den Clausenske Injuriesag«, der førte til, at Grundtvig på ny blev betragtet som en forfatter, man kunde have respekt for, selv om man ikke i ét og alt var enig med ham.

Men hvorpå beroede denne ændrede holdning egentlig?

Det var efter min opfattelse ikke blot en kirkepolitisk ændring. Det var slet ikke en ændret livsanskuelse. Det var faktisk en ændret holdning over for samtidens videnskab - men det var intet knafald for de dominerende opfattelser inden for teologi, naturvidenskab, humaniora og filosofi. Grundtvig vedblev at anse »den Mosaisk-Christelige Anskuelse af Livet $\mathrm{i}$ alle sine Retninger og alle sine Yttringer « for »den eneste guddommeligt sande og eviggiældende «. Men han havde nu endelig lært at skelne »skarpt mellem Kirke og Skole, Tro og Vidskab, Timeligt og Evigt«, og han vilde ikke længere »paanøde enten Stat eller Skole en kirkelig Skikkelse«, som det hedder 1833 i fortalen til »Haandbog i Verdens-Historien«. Men han fandt det stadig nødvendigt at sige, at lige så kraftigt må den kristne kirke »tilbagevise ethvert Fors $\varnothing g$ af Stat og Skole paa at omdanne den efter Tykke«. - Han fastholdt altså den apostolske trosbekendelse som kriteriet på ægte kristendom - ikke som et umuligt krav til den menneskelige fornuft, men som tegnet på, at mennesket bøjer sig for det overmenneskelige. Grundmotivet i hans tænkning var at forhindre og modsige de forfalskninger af kristendommen, som datidens teologi var på nippet til at lade sig forlede til.

Man var og er tilbøjelig til at opfatte Grundtvigs kristendomsopfattelse som overtro, fordi man stadig opfatter den menneskelige fornuft som den $\emptyset$ verste instans for al tro. Det er denne overtro på fornuften, Grundtvig allerede i Danne-Virke 
indså og bekæmpede. Men de ovenfor citerede linier præciserede det nye kulturprogram, Grundtvig fra 1832 til sin død hævdede, og som han i 1832 havde indvarslet med de velbekendte verslinier fra indledningsdigtet til »Nordens Mythologi«:

Frihed lad være vort Løsen i Nord,

Frihed for Loke saavelsom for Thor,

Frihed for Alt, hvad der stammer fra Aand,

Som ikke ændres, men arges ved Baand,

Bundet kun være det glubende Dyr,

Som i sit Svælg vil det Ædle begrave!

\section{Om Grundtvigs religiфse udvikling}

Hver gang Grundtvig gjorde et skridt i sin religiøse udvikling, har han indset og indrømmet en fejl. Han har - som de fleste børn - tænkt over disse ting allerede som lille dreng i præstegårdshaven, hvor han lå og »grunded paa, hvordan Gud dog kunde gaa Oppe paa de tynde Skyer « (digtet »Udby Have« fra 1811, US II s. 127.) Og han har grublet over dem i sine sidste digte (f.eks. »Alle Ting er underlige, Ingen kan det grandske ud, At Gud vil til Jord nedstige, For at fæste sig en Brud...« Grundtvigs Sang-Værk V nr. 347 fra 1870). I april 1801 forkastede han ortodoksien, i september 1805 rationalismen. I sin dimis-prædiken marts-april 1810 erklærer han »Videnskabeligheds høiere Egne« for »den eneste Hiemvei« til troen, men tilføjer:

»Dog er det ogsaa blot den Vankundige, som trænger til Kristus, have vi virkelig en Kæde i Haand som vi selv befæstede mellem Solene i den høie Hvælving? Hvo som har den, lad ham ynkes over mig! jeg bekender frit, jeg har den ei.» (US II s. 12f.)

Og i december samme år indså han, at hans fejl ikke var i fornuften, men i hjertet (hvor man nødigst vil søge den, som det senere hedder i Danne-Virke). Derfor bøjede han sig for sine forældre. Men følgerne var frygtelige. Frygteligst var adskillelsen 
fra vennerne, især fra Christian Molbech. Men Grundtvig tvang sig selv til at drage konsekvensen: at forlange af dem, at de skulde gå samme vej som han. - Under den krise, som dommen i 1826 fremkaldte hos ham, må det på et eller andet tidspunkt være gået op for ham, at det var dér, han atter havde gjort fejl: i hjertet, ved at $\varnothing$ ve tvang.

Det var ingen fejl, at han i 1805, under fortvivlelsen, havde valgt livet i stedet for døden. Det var ingen fejl, at han $\mathrm{i}$ januar 1811 havde valgt kapellanembedet i Udby i stedet for karrièren i København. Det var i og for sig heller ingen fejl, at han ved udgivelsen af »Norners og Asers Kamp « havde omvendt de hedenske helte til kristendommen, for en sådan omvendelse havde fundet sted i »Beowulf « - det så han i 1815; det var muligt at være kristen og nordisk helt på én gang. Men det var en fejl at opfordre andre digtere til at hykle kristendom i deres digtning. For det er umuligt at tvinge andre til at have samme tro, som man selv har. Det er dette, Grundtvig må have indset efter dommen i 1826.

Hvorledes dét er gået til, véd vi ikke. Vi kan kun forestille os, hvorledes det er gået op for Grundtvig, at man må indrømme modstanderen den samme ret som den, man kræver for sig selv. Fejlen var atter dér, hvor han nødigst vilde finde den: $\mathrm{i}$ hjertet. Det må være dét, Clara Bolton har vist ham under den eneste samtale, han har haft med hende.

Hun var den eneste, han i det fremmede land kunde tale med om det, der inderst inde bevægede ham: hans situation i dansk åndsliv - eller som han så det: kristendommens situation, som han mente at repræsentere. Nu havde han i England set - ikke blot at gudsdyrkelsen var fri (som det hedder i hans indlæg om folkekirken på rigsdagen i 1849), når blot den ikke var katolsk, men også at Clara Bolton kunde tale frit med ham om de religiøse spørgsmål, som optog hende. Hun kendte jo ikke blot jøden Disraëli, men også den unge Alexander, der så gerne vilde være præst, som Kaj Thaning har vist os i sin artikel »Hvem var Clara?« (Grundtvig-Studier 1985). Hun var ikke blot erotisk tiltrækkende. Hun var et menneske, han kunde tale med om de ting, som optog dem begge - og det var dét, Grundtvig savnede mest af alt. Han har næppe diskuteret Beowulf med hende, rimeligvis heller ikke nordisk mytologi. Men religion var hun levende optaget af. Hun stammede fra Nederlandene, så hun har 
rimeligvis været reformert - ligesom Constance Leth. Danske forhold har sikkert været hende meget fremmede; så det har været naturligt, at han har fortalt hende om sin egen situation. Det eneste, vi véd om deres samtale, er de ord, Grundtvig citerer af hende i digtet »Clara

»Den Ting er ikke i Verden til,

Hvorom vi To jo kan tale sammen!«

(Se Grundtvig-Studier 1985, s. 9)

De ord har Grundtvig aldrig glemt. Han har ladet digtet trykke i Danskeren 1848 - som modsætning til sin samtale med Madvig på rigsdagen! »De findes til Lykke, som yndes! « som omkvædet lyder, også efter de ovenfor citerede ord. „Det måtte da være min ret at skrive, som jeg skrev imod den teologiske professor « har Grundtvig sagt. "Ja, men så var det da også hans ret at skrive, som han havde skrevet i sin bog! Han må da have samme ret, som De kræver for Dem!« har hun vel svaret. - Om det er sådan, det er gået til, har vi ingen viden om. Men det, Grundtvig talte med Clara Bolton om, har på ny sat ham i gang som digter - det ser vi af digtet "Smaafruerne« (de pågældende strofer er genoptrykt i Grundtvig-Studier 1985 og citeret af Thaning sammesteds.) Hun har vist ham, at man kan være en alvorlig kristen og samtidig tænke og føle som et frit menneske. Det er sådan, Kaj Thaning har vist at hun var. Derfor er det rimeligt at forestille sig, at hun har løst op for den situation, han havde låset sig fast $\mathrm{i}$ ved sit krav om H.N. Clausens afgang som professor.

Der er for mig al mulig grund til at tro, at det er Clara Bolton, der har overbevist Grundtvig om, at man - selvfølgelig! - må indrømme andre den ret, man kræver for sig selv. - Og dermed til at tænke frit. - Sådan var det at leve i et land, hvor man ikke blev tvunget til at være medlem af statskirken, den anglikanske kirke - og endnu mindre til at være præst $\mathrm{i}$ den. Et land, hvor man kunde tale med kvinder om religion og kristendom! Har Grundtvig talt med Lise om kristendom? - Det véd vi ikke. Men vi véd, at han talte med Marie Toft om kristendom - ja, endda, at de først var uenige, men at hun overbeviste eller overtalte ham til at godkende den »gudelige Forsamling«, hun tilhørte og at det var dét, der tændte den erotiske glød hos ham. Måske har han oplevet noget lignende med Clara Bolton, men på en 
helt anden måde. Det véd vi ikke. Alt, hvad jeg her har skrevet om Grundtvig og Clara Bolton, er kun forestillinger om det mulige.

\section{Om Grundtvigs frihedsbegreb}

Grundtvig bøjede sig for sine forældre i 1810-11. Men han bøjede sig ikke for samtidens videnskab i 1832. Han bøjede sig for friheden. Men han tog ordet og begrebet frihed i en anden betydning, end den, han havde fundet i samtidens filosofi, hvor den betød personlighedens frihed $i$ kraft af den menneskelige fornuft. Når det kom til stykket, betød friheden menneskets uafhoengighed af Gud. Det, Grundtvig bøjede sig for, var medmenneskets frihed over for mig - som en konsekvens af min frihed over for min naste, mit medmenneske. Ikke min frihed over for Gud, omend jeg er frit stillet, om jeg vil tro på ham eller ej, om jeg vil gøre hans vilje eller ej. Han er skaberen, derfor er jeg afhængig af ham - ligesom alle andre skabninger, hele skaberværket.

Begrebet frihed havde hidtil haft en tvetydig klang i Grundtvigs $\varnothing$ ren. Derfor havde han ikke brugt det i sin tænkning. På den ene side havde han fra barnsben ytret sig frit over for sine opdragere: sine forældre i Udby og sine lærere i Tyregod og Århus. Og han havde hævdet retten til trykkefrihed i sin artikel »Om Videnskabelighed og dens Fremme« fra 1807 - med en vigtig fodnote om den hårde skæbne, hans ven P.N. Skougaard havde lidt p. gr. af sin kritiske omtale af Korfits Ulfelds fængsling på Hammershus. På den anden side var Grundtvig fra 1810 stærkt kritisk over for den brug af frihedsbegrebet, som samtidens førende tænkere gjorde i deres filosofi. I oktober 1813 - i manuskriptet »Om Menneskets Vilkaar« - gennemtænkte Grundtvig spørgsmålet om menneskets afhængighed eller uafhængighed af tiden og kom til det resultat, at mennesket er afhængigt af tiden ved fødsel og død. Da han i 1815 så, at Kant opfattede tid og rum som blot aprioriske kategorier i den menneskelige fornuft, måtte han vende sig mod ham og hele den efterkantiske filosofi.

Men endnu vigtigere er det, at Grundtvig i indledningen til sin Verdens Krønike 1814 gennemtænkte det udtryk i Bibelen, at Gud har skabt mennesket »i sit Billede«. Han forestiller sig her, 
»at ligesom Skaberen maatte ville, at al hans Skabning skulde lyde Ham, saaledes maatte Han ogsaa ville, at hver Skabning med Villie skulde lyde Ham med Villie, thi ellers var der jo Noget, som ikke lød Ham, og Mennesket kunde ikke ville lyde Ham uden at være vis paa Hans Liv og Herskab.« (Kort Begreb af Verdens Krønike, betragtet i Sammenhæng, s. 16. Se Grundtvig-Studier 1986 s. 8. Udhævelsen er Grundtvigs.)

Disse ord forekommer mig overordentlig bemærkelsesværdige og ejendommelige.

1) fordi de ikke stiller lydigheden mod Gud i modsætning til menneskets egen vilje,

2) fordi de hævder, at det er Guds vilje, at mennesket skal lyde Gud med hele sit vaesen, og derfor også med sin egen vilje,

3) fordi Grundtvig forudsætter, at mennesket er skabt med en egen vilje og tillige med viden om Guds eksistens og herredømme over verden.

(At denne egen vilje er fri, fremgår ikke af Grundtvigs fremstilling, men ligger i Bibelens ord, som de er oversat i den Bibel, Constance Leth havde foræret ham, og som han brugte for Det gamle Testamentes vedkommende. Her står i 1. Mosebog kap. 2 v. $16-17$ :

»Og Gud HERREN bød mennesket, og sagde: du maa frit æde af alle træer i haven. Men af kundskabens træ paa got og ont, af det skal du ikke æde: thi paa hvilken dag du æder af det, skal du døe døden.«)

At mennesket har en fri vilje, ligger ifølge Grundtvig deri, at det er skabt i Guds billede og efter hans lignelse, dvs. som et billede af den treenige Gud, ikke fuldkomment, men bestemt til at ligne Gud mere og mere gennem tidens løb, således som Grundtvig fremstiller det i Verdens Krønike 1814, jf. optrykket deraf i Grundtvig-Studier 1986. - Således tænkte Grundtvig altså, og dette filosofiske grundlag for sit historie- og menneskesyn har Grundtvig holdt fast ved hele sit liv, fordi han derved grundlagde 
sin opfattelse af treenigheden og dermed af den apostolske trosbekendelse. Vi véd fra provst Frederik Schmidts dagbogsbeskrivelse af sit ophold i København i 1811, at Grundtvig var urokkelig mht. treenigheden under sine samtaler med sine norske venner, spec. professor Treschow på Valkendorfs kollegium.

Man må af den citerede passus fra Verdens Krønike 1814 slutte, at Grundtvigs lydighed mod Gud og - i konsekvens heraf - mod sine forældre i januar 1811 ikke er at betragte som en slaveagtig eller sygelig masochistisk underkastelse, men som udtryk for en dybtgående erkendelse af, at mennesket ikke er et uafhængigt væsen i universet, men et væsen med en egen vilje, der enten kan være lydig eller ulydig mod skaberen, og hvis vilje derfor er fri.

Det var altså ingen ny, men en gammel erkendelse, der blev virksom hos Grundtvig, da han i 1831 gjorde H.N. Clausen den indrømmelse, at han måtte have den samme ret og dermed frihed til at hævde sit synspunkt, som Grundtvig hævdede for sit vedkommende. Troen var ingen ægte tro, hvis ikke mennesket »lød Gud med Villie«, som det så ejendommeligt og klart er udtrykt i Verdens Krønike 1814.

Man vil måske efter denne fremstilling forestille sig, at den kun har betydning for den specielle Grundtvig-forskning. Sådan tror jeg dog ikke det forholder sig, eftersom Grundtvig fik den betydning, han fik i sin samtid og eftertid. Hvis denne betydning skal fortsætte i fremtiden, tror jeg at kendskabet til og fordybelsen $\mathrm{i}$ hans liv og forfatterskab vil være nødvendig. 